\title{
Factors Enhancing Level of Entrepreneurship based on Characteristics of Staff Managers in Ministry of Education \\ Naseri Saeed ${ }^{1}$, miransari Mohsen ${ }^{2}$, shahrakipour Hasan ${ }^{3}$ \\ ${ }^{1}$ School of Education and Counseling Phd student of educational planning Azad University Saeed Naseri <saeednaseri110@yahoo.com \\ ${ }^{2}$ School of Education and Counseling Lectur of educational managment Baghiyatallah University mmiransari@yahoo.com \\ ${ }^{3}$ School of Education and Counseling Lectur of educational managment Azad University hshahrakipour44@gmail.com
}

\begin{abstract}
The aim of this study was to investigate the factors affecting the promotion of entrepreneurship that based on personality traits of managers and staff of the Ministry of the Education, the population consists of all managers of the ministry of education that the number of 157 people of which 113 were selected as statistical sample, standard entrepreneurship questionnaire was used to collect data. To determine its validity and faculty supervisor and consultant enjoyed. In order to assess the reliability of the test, 35 copies of questionnaires were distributed among respondents; the Cronbach's alpha coefficient was 0.75 after collecting the questionnaires and entering into SPSS software.
\end{abstract}

Results from this study indicate that questions based on the promotion of entrepreneurial personality characteristics and problem-solving ability, there is significant direct relationship.

\section{Indexing terms/Keywords}

Entrepreneurship, Managers' character, Education administration staff area

\section{Council for Innovative Research}

Peer Review Research Publishing System

\section{Journal: Journal of Social Sciences Research}

Vol. 5, No. 2

Jssreditor.cir@gmail.com

www.jssronline.com 


\section{INTRODUCTION}

Human force is known as an unlimited resource and the center of all kinds of developments in this century. Among these unlimited resources, "entrepreneurs" possess extraordinary power. Paying attention to these people is actually looking at a certain group who plays a crucial role in educational development and efficiency improvement. Entrepreneurship, has existed since human beings were created. In other words, entrepreneurship is considered as the core of any work, effort and human improvement in the modern world. It is the process of establishing and improving jobs and businesses based on a new creative idea.

Entrepreneurship is a process through which satisfaction and new demand is generated; or in other words, it is the use of proper managerial techniques and concepts, observing educational standards, and applying design tools and processes. Paying more attention to entrepreneurs can greatly help in solving organizational problems and increasing efficiency and effectiveness. From one aspect, knowing managers' psychological characteristics and its relation to the rate of entrepreneurship is a good step towards improving their work efficiency. Huge numbers of studies around the world have looked at this subject. In most of developed as well as developing countries, entrepreneurship is seen as the most fundamental aspect of development. It is so important that in the west and some other countries, the last two decades are called "golden decades" (Hezarjaribi,2004, p.74). Also, Gartner (1990) acknowledges creativity as the main essence of entrepreneurship.

Generally, personal characteristics are the criteria for differentiating between entrepreneurs and non-entrepreneurs. The most well-known and accepted characteristics among scientists are introduced as: need for high success (McClelland, 1961) and internal control for taking risks (Brockhous, 1980).

Also, Hubert and Link (2001) have suggested the four important aspects of entrepreneurship, namely taking risks, innovation, understanding change, and uncertainty as "entrepreneurship square. Having systematic planning based on different aspects of managerial needs, organizational infrastructure, and human resources personal characteristics will help us in two things. First, in moving toward combining entrepreneurship and education system and resolving usual problems in education; second, in benefiting from creative and skillful individuals for solving problems in education system for continuous improvement. Today, improving staffs and managers' capabilities and competency, and preparing them entrepreneurially to match the society needs in various domains is one of the required achievements of the country's education system, especially from staff managers' strategic decisions.

In order to remove the obstacles in improvement of education system, it is essential to recognize the factors which affect entrepreneurship and personal characteristics of human resources. This is possible in the light of having effective entrepreneurial education system including curriculum design, education and research technologies, and educational management. Hence, researcher who has several years of experience in entrepreneurship in education and appreciates human resources in education, conducted this study in order to provide educational policy makers with scientific and practical approaches for establishing and emphasizing entrepreneurship in educational systems.

\section{STATEMENT OF THE PROBLEM}

Value creation through recognizing opportunities and innovations is done by entrepreneurship (Sepehri, 2009 cited to Yadollahi, 2009). Canada and some Asian countries including Philippines, India, and Malaysia have taken big steps to support entrepreneurial activities. Entrepreneurship has not only been established as a university course in different fields, but considered in various education levels from preliminary to high school (Ahmadpourdariani, 2005,p.23).

Huge number of studies conducted both in Iran and majority of developed countries show that the more a society has entrepreneurs, the more dynamic and active it would be. It will result in creation of value added job opportunities (Asemipour, 2000;jalalipour, 2000; Shompeter, 1985). Paying attention to entrepreneurship as a tool for development started since early 20th century. Today, most countries invest greatly in entrepreneurship. It has an important role in the countries stable development. Some reasons for this importance are:

1- Improving social and individual life quality: it is believed that individuals can have better lives by entrepreneurial knowledge, skill, and attitude.

2- Social justice: history is full of discriminations which caused poverty in parts of the society. To compensate this lag, entrepreneurial development is a good solution. It helps incomes to be distributed among all members of society and reduces inequalities.

3- Social responsibility: members of a society need entrepreneurial capacities to do their social responsibilities.

4- Environmental responsibility: entrepreneurial capacities reinforce individuals' viewpoint towards stable development and environmental protection.

5- Development of society's production capacity: entrepreneurs can foster society's production capacity, economic growth, and social welfare by creating new careers and job opportunities, enhancing the existing careers, and by utilizing the unused capacities.

6-solving society's problems: entrepreneurs solve the issues and problems of society by innovation and uninterrupted effort.

Creating entrepreneurial opportunities, increasing mangers' interest and motivation for doing entrepreneurial activities, and building mechanisms of support and guidance are the signs of developing activities in a country. This way, 
entrepreneurship development finds it inclusive definition. It includes the creation of new jobs, enhancing the existing careers, resolving the problems of societies, government, and corporations, as well as enhancing the quality of social and individual life(Yadollahifarsi, encyclopedia of entrepreneurship, 2009, p.15). But, Shan and Necataraman (2002) claim that entrepreneurship is the existence of opportunities, exploring and then utilizing them. As Cheng \& Low (2006) asserts, entrepreneurship is stabilized only by the process of recognizing and valuing opportunities and then possessing them.

The engines of education and economy development are always running by entrepreneurship development. Today, teaching entrepreneurship has become one of the most important activities in universities. Research on entrepreneurship, promotion and dissemination of its concept, preparing cultural support for entrepreneurship, and most importantly cultivating (especially educated) staff entrepreneurs is of utmost importance for developing societies like Iran. Because today's evolution and development is centrally based on merit-oriented societies where entrepreneurship is regarded very crucially (Asemipour, 2000, p. 56). External environment, organization, managerial strategy, activity, and support are of influential factors in advancing organizational entrepreneurship ((Guth \& Ginsberg, 1990; Miller, 1983; Kuratko, 2003).

\section{RESEARCH OBJECTIVES}

Investigation and recognition of factors which enhance the level of entrepreneurship in staff managers of Education Ministry based on personal characteristics. Investigation and determination of level of entrepreneurship in staff managers of Education Ministry based on personal characteristics

\section{RESEARCH METHOD}

From the objectives point of view, the present study is an applied research and from analysis aspect it is a quantitative survey which is descriptive correlation.

For collection of statistic data and determining variables a survey was conducted by using questionnaires. Research method is based on correlation assumptions.

\section{POPULATION AND SAMPLE}

The population for this research consisted of 157 staff managers of Ministry of Education. To choose method, 113 of managers were selected based on Morgan's Table as samples. Questionnaires were distributed among them and they were selected based on simple random sampling.

\section{DATA COLLECTION INSTRUMENTS}

According to the topic, objectives, and research questions researcher used survey and standardized entrepreneurship questionnaires based on personal characteristics and a questionnaire for problem solution.

\section{VALIDITY OF QUESTIONNAIRES}

Investigation tools for this study were standardized entrepreneurship questionnaires which were adapted by taking advantage of several sources; by changing their structure and scale and the feedbacks from respectful supervisors and counselors. Questions were approved and endorsed after corrections. In addition to demographic questions, this questionnaire had 35 items in 5-option likert scale which was considered based on interval scale.

\section{RELIABILITY OF QUESTIONNAIRES}

A number of 30 questionnaires were distributed to pilot the reliability. After collection of these questionnaires, their reliability coefficiency was tested by using SPSS18 software and Cronbach's Alpha (0.75) model. The result for personal characteristics' alpha was 0.77 , for problem solution 0.84 , and for the level of entrepreneurship was 0.87 .

\section{RESEARCH FINDINGS}

In the inferential statistics by assuming that data were normal, T-test from two different groups, variance analysis, Pearson correlation coefficient, and regression testing were used.

\section{INFERENTIAL ANALYSIS OF DATA}

A) Descriptive information

Table 1. Table results of T-test of two different groups(gender)

\begin{tabular}{|c|c|c|c|c|c|}
\hline Research Question & Gender & N & Mean & SD & MD \\
\hline $\begin{array}{c}\text { Is there any correlation between } \\
\text { enhancing entrepreneurship among staff } \\
\text { managers of Education Ministry and } \\
\text { their personal characteristics? }\end{array}$ & F & 39 & 4.37 & 0.28 & $\mathbf{0 . 0 4 4}$ \\
\cline { 2 - 7 } & M & 73 & 4.46 & 0.28 & $\mathbf{0 . 0 2 5}$ \\
\hline
\end{tabular}


B) Results of Test

\begin{tabular}{|c|c|c|c|l|l|l|l|}
\hline \multicolumn{2}{|c|}{$\begin{array}{l}\text { Research Question } \\
\text { equation }\end{array}$} & \multicolumn{3}{|l|}{$\begin{array}{l}\text { T-Test for comparison of } \\
\text { variance }\end{array}$} \\
\hline $\begin{array}{l}\text { Is there any correlation between } \\
\text { enhancing entrepreneurship among } \\
\text { staff managers of Education Ministry } \\
\text { and their personal characteristics? }\end{array}$ & F value & $\begin{array}{c}\text { Level of } \\
\text { significance }\end{array}$ & Std & MD & sig & df & $t$ \\
\cline { 2 - 8 } & 0.5 & 0.685 & 05 & 086 & 12 & 11 & 56 \\
\cline { 4 - 9 } & & & 0.5 & -0. & 0.1 & 0 & -1.2 \\
\hline
\end{tabular}

Based on the part A of table 1, the mean of females' opinion is lower than males'. But, the test of comparison of means shows that these differences were not significant (\%95). In other words, there is no significant difference between the opinions of males and females.

Table 2. Table results of variance analysis of research questions according to participants' education level

\begin{tabular}{|c|c|c|c|c|c|c|}
\hline Research Question & sig & F & MS & df & ss & $\begin{array}{c}\text { Change } \\
\text { resources }\end{array}$ \\
\hline $\begin{array}{l}\text { Is there any correlation between } \\
\text { enhancing entrepreneurship among staff } \\
\text { managers of Education Ministry and their } \\
\text { personal characteristics? }\end{array}$ & 0.8 & 0.0 & 0.079 & 110 & 8.650 & BG \\
& & & & 112 & 8.716 & WG \\
\end{tabular}

Table 2 displays the results of one-way (unilateral) variance analysis test, according to participants' level of education. As you can see: there is no significant difference between the opinion of participant groups and their education (Bachelors, Masters', PhD, or higher).

Table 3. Table results from variance analysis of research questions according to participants' field of study

\begin{tabular}{|l|l|l|l|l|l|l|}
\hline Research Question & Sig & F & MS & df & SS & $\begin{array}{c}\text { Change } \\
\text { Resources }\end{array}$ \\
\hline $\begin{array}{l}\text { Is there any correlation between enhancing level of } \\
\text { entrepreneurship among staff managers of Education Ministry } \\
\text { and their personal characteristics? }\end{array}$ & 0.1 & 3.94 & 0.075 & 110 & 8.224 & WG \\
\hline
\end{tabular}

Table 3 shows the results of variance analsysi test about the opinions of participants according to their field of study. It shows that there is no significant difference in participants' opinions (\%95), but the difference in their personal characteristics is significant. To recognize different groups, the results of Duncan's test are provided in table 4.

Table 4. Table results of Duncan's test for recognition of different groups of education level

\begin{tabular}{|l|c|c|c|}
\hline Field of Study & N & \multicolumn{2}{|c|}{ Significant level in \%95 } \\
\cline { 3 - 4 } & & 1 & 2 \\
\hline Other educational fields & 31 & 4.3274 & 4.444 \\
\hline Other fields & 55 & 4.444 & 4.506 \\
\hline Educational management & 27 & & 0.347 \\
\hline Level of Significance & & 0.081 & \\
\hline
\end{tabular}

There is no significant difference between the participants form other educational fields and other non-educational fields. But, the difference is significant (\%95) between participants graduated from educational management and other fields. And also, there is no significant difference between graduates of educational management and other educational fields.

Table 5. Table results from variance analysis of research questions according to participants' Organizational position 


\begin{tabular}{|l|l|l|l|l|l|l|}
\hline \multicolumn{1}{|c|}{ Research question } & Sig & F & MS & df & SS & $\begin{array}{l}\text { Change } \\
\text { resources }\end{array}$ \\
\hline $\begin{array}{l}\text { Is there any correlation between enhancing level of } \\
\text { entrepreneurship among staff managers of Education } \\
\text { Ministry and their personal characteristics? }\end{array}$ & 0.162 & 1.670 & .127 & 4 & 0.508 & $\mathrm{BG}$ \\
& & & .076 & 108 & 8.209 & WG \\
& & & 112 & 8.716 & $\mathrm{~T}$ \\
\hline
\end{tabular}

Data in table 5 shows that there is no significant difference among participants in various organizational positions.

Table 6. Table results from variance analysis of research questions based on participants' years of service

\begin{tabular}{|l|l|l|l|l|l|l|l|}
\hline Research question & Sig & F & MS & df & SS & $\begin{array}{l}\text { Change } \\
\text { resources }\end{array}$ \\
\hline $\begin{array}{l}\text { Is there any correlation between enhancing level of } \\
\text { entrepreneurship among staff managers of Education Ministry } \\
\text { and their personal characteristics? }\end{array}$ & 0.2 & 1.5 & .076 & 109 & 8.267 & WG \\
& & & & 112 & 8.716 & T \\
\hline
\end{tabular}

Data in table 6 displays that there is no significant difference among participants based on their years of service. In other words, participants with different years of service had almost the same answers about questions.

Table 7. Table results from variance analysis of research questions based on participants' hours of attending training courses

\begin{tabular}{|l|l|l|l|l|l|l|}
\hline Research question & Sig & F & MS & df & SS & $\begin{array}{l}\text { Change } \\
\text { resources }\end{array}$ \\
\hline $\begin{array}{l}\text { Is there any correlation between enhancing level of entrepreneurship } \\
\text { among staff managers of Education Ministry and their personal } \\
\text { characteristics? }\end{array}$ & 0 & 0 & 0.078 & 110 & 8.569 & WG \\
& & & & 112 & 8.716 & $\mathrm{~T}$ \\
\hline
\end{tabular}

Data in this table describes that there is no significant difference among participants with different hours of attending inservice training courses. In other words, participants had almost similar opinions about the questions.

Table 8. Table results from regression test

\begin{tabular}{|l|l|l|l|l|l|l|l|}
\hline $\begin{array}{l}\text { Statistical } \\
\text { model }\end{array}$ & $\begin{array}{l}\text { Input } \\
\text { variables }\end{array}$ & $\begin{array}{l}\text { Cancel-out } \\
\text { variables }\end{array}$ & $\begin{array}{l}\text { Statistical } \\
\text { method }\end{array}$ & $\mathbf{R}$ & $\mathbf{R 2}$ & $\begin{array}{l}\text { Proven } \\
\text { R2 }\end{array}$ & $\begin{array}{l}\text { Error } \\
\text { estimation }\end{array}$ \\
\hline 1 & 0.995 & - & Enter & $\begin{array}{l}995 \\
0 .\end{array}$ & $\begin{array}{l}990 \\
0 .\end{array}$ & 0.990 & 0.0279 \\
\hline
\end{tabular}

Table 8. Table continued: results from regression test

\begin{tabular}{|c|c|c|c|c|c|}
\hline \multirow[t]{2}{*}{ Model 1} & \multicolumn{2}{|c|}{ Non-standard Significance } & \multirow{2}{*}{$\begin{array}{c}\begin{array}{r}\text { Standard } \\
\text { Significance }\end{array} \\
\text { Beta }\end{array}$} & \multirow[t]{2}{*}{$\mathbf{T}$} & \multirow[t]{2}{*}{ sig } \\
\hline & $\overline{\mathrm{SL}}$ & $\mathrm{B}$ & & & \\
\hline Constant & -0.014 & 0.042 & & $0 / 333$ & $0 / 740$ \\
\hline Question 1 & 0.696 & 0.017 & 0.691 & $40 / 406$ & $0 / 000$ \\
\hline Question 2 & 0.342 & 0.015 & 0.342 & $20 / 006$ & $0 / 000$ \\
\hline
\end{tabular}

Predictive variable is personal characteristics and predicted variable is managers' entrepreneurship.

\section{CONCLUSION AND DISCUSSION}


1 - Is there any correlation between enhancing the level of entrepreneurship of staff managers of Education Ministry and their personal characteristics?

Based on the findings and $T$ test of two different groups there was no significant difference between opinions of male and female mean (\%95). This result proves the findings of Ahmadi's (2011) in studying correlation between personality elements and entrepreneurship because the results of the aforementioned study shows that aspects and personal characteristics and entrepreneurship are correlated.

\section{RECOMMENDATIONS}

According to the findings of the present study, there is a correlation between enhancing level of managers' entrepreneurship and their personal characteristics. So it is suggested that:

1- decision making educational managements to be chosen from individuals who possess characteristics such as risk taking, flexibility, creativeity, self confidence, leadership mentality, sociable interaction, and are decisive, forethoughtful, and realistic as well.

2-Managers who are risk taking, innovative, provident, idealistic, and have uncertainty, understand change, , and have leadership qualities for handling sensitive managerial-educational responsibilities should be chosen to solve educational obstacles and to build the bridge with the colleagues more efficiently.

3- For sensitive-strategic managerial supervision positions individuals should retain characteristics such as understanding of various organizational aspects, ability to recognize and solve problems, choosing the most suitable solution and way for reaching the targeted goals. They must also have creative thinking and systemic attitude.

\section{ACKNOWLEDGMENTS}

Authors would like to thank all of their lectures who guide them during this study and also all their friends who helped them. Their Kindness and guidelines cannot be forgotten in authors' life.

\section{REFRENCE}

[1] Ahmadi, Parviz. 2011. "Journal of Research in Enterprise Resource Planning." Third year, No. 1.

[2] Ahmedpur Dariani, Mahmoud. 2005. Does entrepreneurial strategy alters institutions?, Journal of Science Policy and Research Approaches, No. 29. p.23.

[3] Asemipour, Mohamad Javad. 2000. Assessment of Academic Studies - Application and its impact on productivity. Proceedings of the Second Conference on Science Education of applied analysis. p. 56.

[4] Brockhaus, R. H.1980. "Psychological and Environmental Factors which Distinguish the Successful From the Unsuccessful Entrepreneur: A Longitudinal Study ". Academy of Management Proceedings of the 40th Annual Meeting.

[5] Cheng, Kim \& Low, Patrick, 2006. "Cultural obstacles in growing entrepreneurship: a study in Singapore". Journal of Management Development ; vol. 25, Issue, 2.

[6] Gartner William B 1990. An Empirical Model of the Business Startup, and Eight Entreprencuurial Archetypes, Doctoral Dissertation. University of Washington.

[7] Guth, W.D. \& Ginsberg, A. 1990. Guest editors`introduction: Corporate entrepreneurship, Strategic Management Journal, 11(5-6): 5-15.

[8] Hezarjaribi, Jafar. 2004. Entrepreneur, Publications: Institute of Economic Affairs, First Edition, p.74.

[9] jalalipour, Yavar. 2000. Survey of graduates working directory in the city of Tehran, the Tehran Province.

[10] Kuratko, Donald F. 2003. "Entrepreneurship Education: Emerging Trends and Challenges for the 21st Century". Coleman White Paper Series.

[11] McClelland, D. C. 1961. The achieving society. Princeton, NJ: Van Nostrand Co .

[12] Miller, D. 1983. "The Correlates of Entrepreneurship in Three Types of Firms" Management Science, vol.29.

[13] Schumpeter, Josph. 1958.capitalism, Socialism, \& Democracy. New York: Simon \& Scuster

[14] Yadollahi, Farsi. 2009. Entrepreneurship Encyclopedia, Encyclopedia of Foundation, Labour and Social Security Institute Statue silver printing, p.15. 
Author' biography with Photo

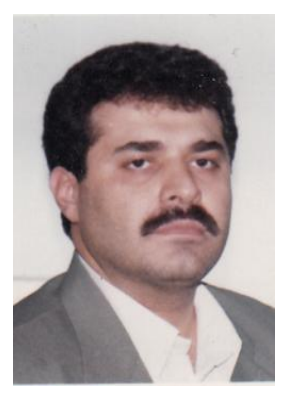

